\title{
СТРУКТУРА МІКРОБНИХ АСОЦІАЦИЙ ПІХВИ У ЖІНОК З ЗАПАЛЬНИМИ ЗАХВОРЮВАННЯМИ ОРГАНІВ МАЛОГО ТАЗУ (ЗЗОМТ)
}

\author{
${ }^{1}$ Лісяна Т. О., к.б.н., завідуюча лабораторією мікробіології \\ ${ }^{1}$ Кацалап О. І., лікар - бактеріолог \\ ${ }^{2}$ Салманов А. К., д.мед.н., завідувач кафедри мікробіології, епідеміології та інфекційного контролю \\ ${ }^{1}$ Пономарьова І. Г., к.б.н, старший науковий співробітник лабораторії мікробіології \\ ${ }^{1}$ Украӥна, м. Київ, ДУ «ІПАГ імені академіка О. М. Лук янової НАМН Украӥни»;

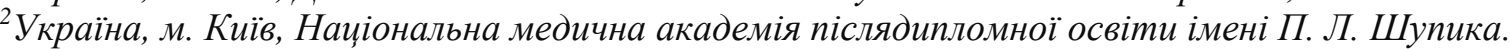

\section{DOI: https://doi.org/ 10.31435/rsglobal_ws/30092018/6135}

\section{ARTICLE INFO}

Received: 11 July 2018

Accepted: 17 September 2018

Published: 30 September 2018

\section{KEYWORDS}

associations of microorganisms, inflammatory diseases of the pelvic organs,

vaginal microbiocenosis.

\begin{abstract}
Inflammatory diseases of the pelvic organs are characterized by the formation on the mucous membrane of the genital tract of multicomponent associations of conditionally pathogenic microflora. In order to evaluate the microbiocenosis of the genital tract during 2013-2017, 554 women with inflammatory diseases of the pelvic organs were examined.

The task of the study included studying the frequency and structure of microbial associations that contaminated the genital tract of women with inflammatory diseases of the pelvic organs and analysis of vaginal microecology changes during 2013-2017. It is established that during the period from 2013 to 2017 , in women with inflammatory diseases of the pelvic organs, an increase in the frequency of registration in the vaginal stems of the conditionally pathogenic microflora associations is observed. In the 2016 and 2017 dominant variants of associations of bacterial flora, the presence of S.epidermidis (heme + ) and S. faecalis vagina was observed in the examined patients. The active proliferation of opportunistic microflora on the mucous membrane of the genital tract in patients with inflammatory diseases of the small pelvis was accompanied by a deficiency of lactobacilli and an increase in specific gravity in the associations of fungi of Candida.
\end{abstract}

Citation: Лісяна Т. О., Кацалап О. І., Салманов А. К., Пономарьова І. Г. (2018) Struktura Mikrobnykh Asotsiatsii Pikhvy u Zhinok z Zapalnymy Zakhvoriuvanniamy Orhaniv Maloho Tazu (ZZOMT). World Science. 9(37). doi: 10.31435/rsglobal_ws/30092018/6135

Copyright: () 2018 Лісяна Т. О., Кацалап О. І., Салманов А. К., Пономарьова I. Г. This is an open-access article distributed under the terms of the Creative Commons Attribution License (CC BY). The use, distribution or reproduction in other forums is permitted, provided the original author(s) or licensor are credited and that the original publication in this journal is cited, in accordance with accepted academic practice. No use, distribution or reproduction is permitted which does not comply with these terms.

Вступ. На сучасному етапі встановлено, що 33ОМТ $є$ поліетіологічними та характеризуються формуванням на слизовій оболонці статевих шляхів багатокомпонентних асоціацій умовно-патогенної мікрофлори та інших інфекційних збудників $(1,2)$.

Вивчення механізмів утворення мікробних асоціацій, взаємодія сімбіонтів в мікросімбіоценозі, зміна біологічних властивостей асоціантів $є$ одним 3 пріоритетних направлень розвитку мікробіології (3).

Відомо, що активація синтезу бактеріями факторів патогенності відбувається в умовах зростання щільності їх популяції та при наявності відповідних міжклітинних комунікативних зв'язків. Регуляція цих процесів $\epsilon$ наслідком виділення бактеріями в оточуюче середовище речовин з встановленою хімічною структурою (4). 
Зокрема такими агентами $\epsilon$ ацетильовані лактони гомосерина, що регулюють комунікативні процеси у грамнегативних бактерій та пептиди, які відповідають за експресію факторів патогенності, спороутворення, кон`югативну передачу плазмід та інші функції у грампозитивних бактерій (5).

Встановлено, що мікроорганізми в складі асоціацій характеризуються збільшення резистентності до дії хіміотерапевтичних препаратів та більш стійкі до таких захисних факторів як фагоцитоз, лізоцим, комплемент, антитіла та цитокіни (6).

Літературні дані свідчать, що міжмікробна взаємодія в умовах асоціацій має різні прояви: індиферентна, стимулююча, інгібіюча або інвертуюча. Прояви інверсії означають заміну антагонізму на стимуляцію росту. Відомо, що ефекторами регуляції виступають метаболіти та структури клітинних стінок мікробів-асоціантів $(7,8)$.

Враховуючи, що важливим регулюючим фактором в формуванні мікробіоценоза та мікробних асоціацій $є$ поживні речовини окремої екологічної ніші, мікроби-асоціанти поділяють на метаболічно залежні та метаболічно не пов'язані між собою (9).

Симбіотичні відносини в асоціаціях формуються на основі мутуалістичних зв’язків, коли взаємний обмін продуктами життєдіяльності стає необхідним і обов'язковим для їх існування. Антагоністичні відносини в мікробних асоціаціях реалізуються завдяки різним факторам: продукція антимікробних речовин 3 бактеріостатичною та бактеріцидною активністю, конкуренція за поживні речовини $(10,11)$.

Важливу роль в формуванні асоціацій грає здатність бактерій до біологічної адгезії. В основі біологічної адгезії лежать процеси розпізнавання та ліганд-рецепторної взаємодії, які визначають співіснування макроорганізма хазяїна та мікробних асоціацій $(12,13)$.

Механізми, які змінюють співвідношення між захисною та транзиторною мікрофлорою статевих шляхів або регулюють процес формування та склад бактеріальних асоціацій до теперішнього часу вивчені недостатньо. Існують теорії про вплив на спектр мікробних асоціантів гормонального дисбалансу, змін в системі імунітету, застосування нераціональної терапії та екологічних факторів(14).

В задачі роботи входило вивчення частоти та структури мікробних асоціацій, що контамінують статеві шляхи жінок з 33ОМТ та аналіз змін мікроекології піхви на протязі 2013-2017 років.

Матеріали та методи досліджень. 3 метою оцінки мікробіоценозу статевих шляхів на протязі 2013-2017 років обстежено 554 жінки з 33ОМТ віком від 25 до 38 років.

У обстежених жінок визначали рівень контамінації піхви потенційно патогенною та захисною мікрофлорою, а також грибами р. Candida.

Проведення мікробіологічних аналізів та облік результатів здійснювали згідно нормативним документам МО3 України.

Для висіву досліджуваного матеріалу використовували чашки Петрі з рядом поживних середовищ: кров`яний агар, Ендо, жовточно-сольовий агар, Сабуро, MRS та інші.

Посіви здійснювали методом секторного посіву на щільні поживні середовища, що дозволяє визначити ступінь мікробного обсіменіння та виявити максимально можливий спектр аеробної та факультативно-анаеробної мікрофлори.

Таксономічне положення мікроорганізмів визначали відповідно до «Визначника бактерій Берджі». Ідентифікацію мікроорганізмів проводили за їх культуральними та морфологічними ознаками.

Після підрахування колоній мікрофлори на щільних середовищах дані перераховували в десятинні логарифми від кількості мікробних клітин (lg КУО/мл).

Статистичну обробку отриманих результатів проводили за допомогою стандартних комп’ютерних пакетів « Аналіз даних» Microsoft Exel для Windows 2007.

Результати роботи. Обстеження хворих з 33ОМТ на протязі 2013-2017 років дозволило встановити значну частоту полімікробних асоціацій, що контамінують слизову оболонку статевих шляхів. Домінуюча роль в складі асоціацій належить умовно-патогенним мікроорганізмам, грибам p. Candida та представникам нормальної мікрофлори. Значна частка мікроорганізмів в складі асоціацій входить до філуму Firmicutes. Насамперед це Staphylococcus epidermidis 3 гемолітичними властивостями та ентерокок. Ці мікроорганізми володіють високим колонізаційним потенціалом, мають широкий спектр факторів персистенції та здатність до плівкоутворення.

По результатам проведених досліджень частота асоціативних форм мікробної контамінації піхви в 2013 році та в 2014 роках суттєво не відрізнялась та складала відповідно $58,3 \%$ та $60,5 \%$. 
32015 року зареєстровано збільшення кількості хворих з полімікробними асоціаціями та виявлено тенденцію до поступового зростання частоти реєстрації асоціацій на протязі 2016 та 2017 років $(68,6 \%-71,4 \%)$.

До складу асоціацій входило від двох до п`яти видів мікроорганізмів. На протязі 2013 та 2014 років найчастіше реєструвались двокомпонентні мікробні асоціації (47,8\% - 49,3\%). 32015 по 2017 рік спостерігалась тенденція до зростання частоти формування на слизовій оболонці статевих шляхів трьохкомпонентних мікробних асоціацій (Рис.1).

Частота визначення трьохкомпонентних асоціацій знаходилась в межах 20,5\%-25,7\%. Чотирьох та п'ятикомпонентні асоціації зі слизової оболонки піхви виділялись 3 незначною частотою.

Встановлено 4 варіанти двокомпонентних мікробних асоціацій, які з найбільшою частотою виділялись 3 піхви хворих: I варіант - S.epidermidis $\left(г е \mathrm{M}^{+}\right)$та E.coli , II варіант - S.epidermidis $(г е м+)$ та S. faecalis, III варіант - S. faecalis та E.coli, IV варіант - S.epidermidis $(г е м+)$ та Corynebacterium spp. Виявлено зміну домінуючих варіантів асоціацій умовно-патогенної мікрофлори в різні роки дослідження. Але на протязі всього досліджуваного періоду майже в кожному варіанті був присутній стафілокок епідермальний з гемолітичними властивостями.

Так на протязі 2013 та 2014 років в спектрі мікрофлори зі статевих шляхів жінок переважали асоціації стафілокока епідермального, що мав гемолітичні властивості з ешеріхіями - I варіант ( 2013 p. - 16,6\%, 2014p. - 18,3 \%). В період з 2015p. по 2017p. показники реєстрації I варіанту бактеріальних асоціацій мали тенденцію до зниження (2017 р.- 11,4\%).

Другий варіант асоціацій S.epidermidis (гем+) та S. faecalis в 2013 та 2014 роках реєструвався 3 помірною частотою (11,4\%-14,4\%), але з 2015 року займав домінуючі позиції в складі мікроекології піхви $(18,6 \%-20,0 \%)$.

Третій варіант асоціацій з 2013 по 2015 роки (S. faecalis та E.coli) реєструвався у хворих 3 частотою 12,5\%-10,5\% та в динаміці спостереження до 2017 р. мав тенденцію до збільшення $(12,3 \%-14,3 \%)$.

Показники визначення IV варіанту асоціацій S.epidermidis (гем+) + Corynebacterium spp. в висівах з піхви хворих становили -6,1\%-9,01\%.

Аналіз кількісного рівня окремих видів мікрофлори в складі асоціацій, що контамінували статеві шляхи, дозволив виявити у більшості обстежених зростання концентрації стафілококів 3 гемолітичними властивостями $3 \lg$ 4,0 КУО/мл в 2013 році до $\lg$ 6,0 КУО/мл в 2017 році. Починаючи з 2015 року також зросла кількість S. faecalis (lg 4,0 - $\lg$ 6,0 КУО/мл).

Під впливом антропогенної трансформації середовища може зростати вірулентність, як патогенних так і умовно-патогенних мікроорганізмів, за рахунок ініціації включення або виключення плазмідних генів. Літературні дані свідчать, що негативний вплив середовища може супроводжуватись дисбалансом популяції в мікробних асоціаціях, формуванням колективної стійкості до негативних факторів, посиленням сорбції бактеріями токсичних елементів, маючих канцерогенну та мутагенну активність (12).

В динаміці спостереження зареєстровано зростання питомої ваги в складі асоціацій грибів р. Candida. Так частота реєстрації грибів р. Candida в висівах з піхви в 2013-2015 роках знаходилась в межах 14,6\%-18\%, в 2016-2017 роках досягала 20,3\%-22,9\%.

Зростання частоти реєстрації грибів р. Сandida може пояснюватись застосуванням нераціональних схем терапії, що в подальшому може сприяти розвитку запального процесу. Відомо, що гриби р. Candida в асоціаціях з мікроорганізмами здатні підсилювати свої патогенні властивості. Зокрема в складі бактеріально - грибкових асоціацій мікрофлора збільшує свою гемолітичну та ДНКазну активність, а у грибів зменшується ліполітичні властивості.

У всіх обстежених хворих з асоціативними формами бактеріальної контамінації піхви виявлено дефіцит захисної мікрофлори - лактобацил. Найбільше зниження кількісного рівня висіву захисної мікрофлори виявлено у жінок 3 I та II варіантами мікробних асоціацій. Концентрація лактобацил не досягала рівня норми $(<\lg 6,0$ КУО/мл). 


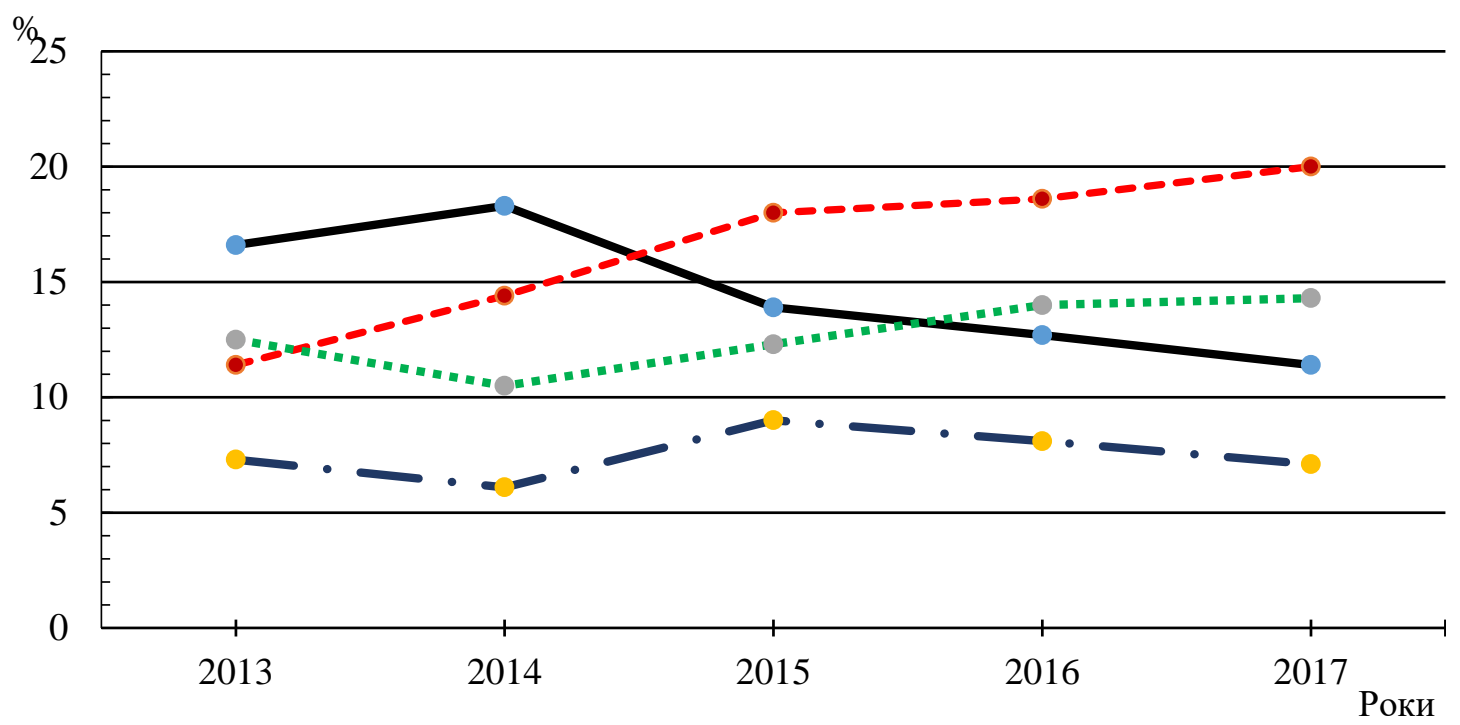

- - I варіант - S. epidermidis ( гем+ ) та E.coli

$-\bullet-$ II варіант - S. epidermidis $($ гем+) та S.faecalis

- - " III варіант - S.faecalis та E.coli

- IV варіант - S. epidermidis ( гем+) та Corynebacterium spp.

Рис. 1. Частота реєстрації двокомпонентних асоиіацій умовно - патогенної мікрофлори, що з найбільшою частотою реєструється в виділеннях з піхви хворих з запальними захворюваннями органів малого тазу.

Аналіз контамінації піхви лактобацилами у цих жінок в динаміці спостереження (20132017 р.) свідчить про відсутність відновлення їх кількісного рівня. Це сприяло формуванню та стабільності дисбіозу піхви у обстежених хворих.

У хворих з III та IV варіантами асоціативного бактеріального обсіменіння піхви кількісні показники висіву лактобацил також не досягали рівня норми $(\lg 4,4-\lg 4,6$ КУО/мл).

Однією 3 важливих функцій нормальної мікрофлори $є$ забезпечення колонізаційної резистентності (КР) організму, що обумовлено механізмами кооперативної взаємодії між індигенною мікрофлорою та макроорганізмом. Ці механізми спрямовані на підтримку стабільності мікросімбіоценоза, збереження автохтонної мікрофлори та елімінацію аллохтонної.

Підсумовуючи результати проведених досліджень слід відзначити, що на протязі з 2013 по 2017 рік у жінок з З3ОМТ спостерігається збільшення частоти реєстрації в висівах 3 піхви асоціацій умовно-патогенної мікрофлори. Домінуючим варіантом асоціацій бактеріальної флори на протязі 2016 та 2017 років у обстежених хворих виявилась присутність на слизовій оболонці піхви S.epidermidis $\left(\right.$ гем$\left.^{+}\right)$та S. faecalis. Серед факторів, які сприяють формуванню мікробних комплексів, значну питому вагу має нераціональне застосування антибіотиків, збільшення в складі асоціацій полірезистентних штамів бактерій. Це пояснюється появою на сучасному етапі нових механізмів розвитку резистентності, клонального розповсюдження резистентних штамів, обміном генами резистентності між мікроорганізмами, навіть філогенетично відмінними один від одного. Зміна домінуючих мікробних компонентів в складі асоціацій в умовах довгострокового спостереження може бути пов'язана як 3 впливом екологічних та соціальних факторів так і з особливостями внутрішньовидової та міжвидової взаємодії умовно - патогенних та облігатних бактерій в зв'язку 3 метаболічними характеристиками окремої екологічної ніші макроорганізму.

Одержані дані свідчать про необхідність контроля за зміною мікроекології статевих шляхів у хворих з 33ОМТ, про доцільність визначення асоціативних форм бактеріальної контамінації, запобігання їх виникненню, необхідність пошуку нових підходів до лікування пацієнтів з уже сформованими багатокомпонентними варіантами бактеріального обсіменіння. 


\section{Висновки.}

1. У хворих з 33ОМТ обстежених на протязі 2013-2017 років виявлено значну частоту реєстрації асоціативних форм мікробної контамінації статевих шляхів 3 домінування в складі асоціацій окремих представників фірмікутів, протеобактерій, а також грибів p. Candida.

2. За досліджуваний період зареєстровано тенденцію до зростання частоти реєстрації мікробних асоціацій, зміну складу асоціантів, а також зростання кількості мікробних компонентів в складі асоціацій, що контамінують піхву у жінок з 33ОМТ.

3. Активна проліферація умовно-патогенної мікрофлори на слизовій оболонці статевих шляхів у хворих з 33ОМТ супроводжувалась дефіцитом лактобацил та збільшенням питомої ваги в складі асоціацій грибів р. Candida.

\section{ЛІТЕРАТУРА}

1. Нургалиева Е. В. Микробиота женских половых органов при гнойно - вопалительных заболеваниях гениталий.// Е. В. Нургалиева, А. О. Духин, А. Е. Гущин// Вестник РУДН Серия_Медицина.-2016.№2.-С.197-200.

2. Кунгурцева Е. А. Взаимоформирование микрофлоры слизистых оболочек открытых полостей различных биотопов у женщин как важный фактор их репродуктивного здоровья. / Е. А. Кунгурцева С. М. Попкова, О. Я. Лещенко// Вестник Российской академии медицинских наук. -2014.-№69(9-10).C.27-32. https://doi.org/10.15690/vramn.v69i9-10.1128

3. Бекпергенова А. В. Формирование ассоциаций облигатно - анаэробных бактерий толстого кишечника человека.//А. В. Бекпергенова, Ю. А. Хлопко, Н. Б. Перунова//Вестник Оренбургского государственного университета.-2017.-№9 (209).-С.51-56.

4. Попкова С. М. Характеристика генов патогенности и геновидовой структуры бактерий рода Enterococcus, выделенных из разных биотопов у жителей г. Иркутска. / С. М. Попкова., А. С. Волокитина, Ю. П. Джиоев, Л. С Козлова// Известия Иркутского гос. ун-та. -2011.-№4 (1).-С.14-24.

5. Рыбальченко О. В. Ультраструктура биопленок при внутривидовом и межвидовом взаимодействии условно - патогенных бактерий./О. В. Рыбальченко В. М. Бондаренко, О. Г. Орлова//Бюллетень Оренбургского научного центра УрОРАН (электронный журнал).- 2014.-№1.-С.1-11.

6. Бабяк А. С. Резистентность микроорганизмов к противомикробным препаратам / А. С. Бабяк, А. В. Полина// Международный студенческий научный вестник. - 2017. - № 6.-С.23-27.

7. Синетар Е. О. Формування біоплівки мікроорганізмами та їх значення у медицині/ Е.О.Синетар // Вісник проблем біології і медицини. - 2018. - Вип.2 (144).-С. 59-63.

8. Окулич В. К. Микробные биопленки в клинической микробиологии и антибактериальной терапии / В. К. Окулич, А. А. Кабанова, Ф. В. Плотников. - Витебск: ВГМУ, 2017. - 300 с. : ил.

9. Недашківська В. В. Біоплівки та їх роль в інфекційних захворюваннях / В. В. Недашківська, М. Л. Дронова, Н. О. Вринчану // Український науково-медичний молодіжний журнал. 2016. № 4. -С. 10-19.

10. Семенов А. В. Характеристика антагонистической активности Staphylococcus aureus при межмикробных взаимодействиях./А. В Семенов// Вестник Томского государственного универитета. Биология. -2011. -№ 3 (15). -С. 56-66

11. Бухарин О. В. Симбиоз - биологическая основа инфекции/ О. В.Бухарин //Вестник Московского Университета. СЕР. 16. БИОЛОГИЯ. -2011. -№ 1.-С.7-14.

12. Ядерна А. Г. Дослідження асоціацій мікроорганізмів урогенітального тракту жінок за допомогою ПЛР в реальному часі /А. Г. Ядерна, Л. П. Голодок, О. В. Хлопова, А. І. Вінніков //Вісник проблем біології і медицини. - 2015. - № 4.- Т.-2(125).-С.275-290.

13. Старішко О. М. Особливості складу мікрофлори урогенітального тракту жінок/ О. М. Старішко. // Вісник проблем біології і медицини. - 2017. - Вип. 1 (135) .- С. 59-63.

14. Oh H.Y., Kim B.S., Seo S.S. The association of uterine cervical microbiota with an increased risk for cervical intraepithelial neoplasia in Korea. Clin Microbiol Infect. 2015;21(7):674. 